\title{
NEW AMINOTHIAZOLYLGLYCYLCEPHALOSPORINS WITH A 1,5-DIHYDROXY-4-PYRIDONE-2-CARBONYL GROUP \\ I. SYNTHESIS AND BIOLOGICAL ACTIVITY OF CEPHALOSPORIN DERIVATIVES LEADING TO MT0703
}

\author{
Hiroko Ogino, Katsuyoshi Iwamatsu, Kiyoaki Katano, Satoru Nakabayashi, \\ Takashi Yoshida, Takashi Tsuruoka*, Shigeharu Inouye \\ and SHINICHI KONDO ${ }^{\dagger}$
}

Pharmaceutical Research Center, Meiji Seika Kaisha, Ltd., 760 Morooka-cho, Kohoku-ku, Yokohama 222, Japan

(Received for publication August 21, 1989)

\begin{abstract}
A series of new aminothiazolylglycylcephalosporins with a mono- or dihydroxypyridonecarbonyl group at the $\alpha$-amino group of the $\mathrm{C}$-7 substituent have been prepared and antibacterial activity of these compounds was investigated. Among them, the compounds having a 1,5-dihydroxy-4-pyridone-2-carbonyl group showed excellent anti-pseudomonal activity. In particular, $\quad(6 R, 7 R)-7-[(R S)-2-(2$-aminothiazol-4-yl)-2-(1,5-dihydroxy-4-pyridone-2-carboxamido)acetamido]-3-[[1-(2-hydroxyethyl)pyridinium-4-yl]thiomethyl]ceph-3-em-4-carboxylate (MT0703, 7g) was found to be a well balanced compound with respect to antibacterial activity.
\end{abstract}

In a previous paper ${ }^{1)}$, we reported that the new aminothiazolyloxyiminocephalosporins with an $N$-alkylcyclopentano $[b]$ pyridiniumthiomethyl group at C-3 showed enhanced antibacterial activity, especially against $\beta$-lactamase-producing strains, and that introduction of a carboxyl group to the C-7 substituent influenced the anti-pseudomonal activity, solubility and toxicity. In recent years, it was reported that penicillin and cephalosporin derivatives ${ }^{2,3)}$ having a catechol moiety exhibit strong activity against Pseudomonas aeruginosa, however its anti-pseudomonal activity is lost through $O$-methylation of the catechol moiety by catechol- $O$-methyltransferase (COMT, EC 2.1.1.6) ${ }^{4}$. Taking these points into account, we designed new aminothiazolylglycylcephalosporins bearing a mono- or dihydroxypyridone instead of a catechol connected at the $\alpha$-amino group through an amide linkage, to improve the anti-pseudomonal activity and the stability to COMT. Recently, MocHIDA et al. reported on the aminothiazolylglycylcephem compounds KT-4697 and KT-4788 with the hydroxypyridone moiety, which had a good activity against Gram-positive and Gram-negative bacteria including $P$. aeruginos $a^{5}$.

In this paper, we describe the synthesis and the antibacterial activity of new cephalosporins that Fig. 1. Structure of MT0703 (7g). have various mono- or dihydroxypyridonecarbonyl groups at the $\alpha$-amino group of the aminothiazolylglycyl side chain, leading to a diastereomeric mixture MT0703 (7g) (Fig. 1) possessing a 1,5-dihydroxy-4-pyridone-2-carbonyl group in the C-7 substituent and a 1-(2-hydroxyethyl)pyr-

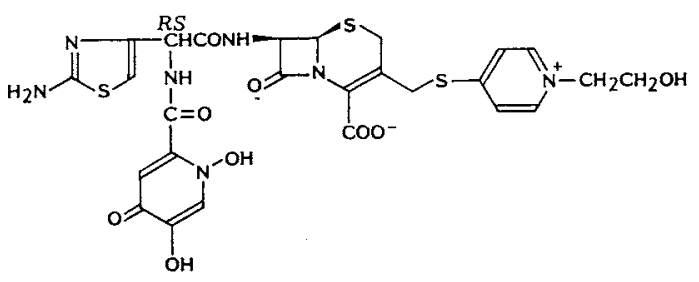

$\dagger$ Present address: Institute of Microbial Chemistry, 3-14-23 Kamiosaki, Shinagawa-ku, Tokyo 141, Japan. 
idiniumthiomethyl group at C-3 as a candidate for clinical use. The synthesis and the antibacterial activity of each diastereomer of $7 \mathrm{~g}$ will be reported in the next paper ${ }^{6)}$.

Chemistry

Aminothiazolylglycylcephalosporins (1) with various mono- or dihydroxypyridonecarbonyl groups were prepared by the method outlined in Scheme 1. An aminothiazolylglycyl derivative (2) was obtained as a 1:1 mixture of diastereomers by reduction ${ }^{7)}$ of the methoxyimino group of cefotaxime (CTX) with zinc powder in aqueous $\mathrm{HCOOH}$. Various mono- and dihydroxypyridonecarboxylic acids were condensed with 2 by the acid chloride or $N, N$-dicyclohexylcarbodiimide (DCC) method, followed by removal of protecting groups, if necessary, to afford corresponding compounds $\mathbf{3 a} \sim \mathbf{3 g}$. Compounds $\mathbf{3}$ were converted into desired products 1 by displacement of the acetoxy group at C-3 methylene with various nucleophiles. Thus, 44 new cephalosporin derivatives have been synthesized as a mixture of diastereomers. Only compounds $3 \mathrm{~b}$ and $\mathbf{6 b}$ (KT-4788) were already synthesized and characterized by Mochide et al. ${ }^{5}$.

New $N$-hydroxypyridone substituents, 1,3-dihydroxy-2-pyridone-6-carboxylic acid (11) and 1,5dihydroxy-4-pyridone-2-carboxylic acid protected as the p-methoxybenzyl ether (15), were prepared according to the route shown in Scheme 2. Compound 11 was prepared from 3-hydroxy-6-pyridone-2carboxylic acid (8) which is easily obtained from D-glucaro-1,5-lactam ${ }^{8}$. The phenolic hydroxyl group of $\mathbf{8}$ was protected by methylation, and the methylated compound was treated with phosphoryl chloride to convert it into chloropyridine 9. Compound 9 was oxidized with hydrogen peroxide in trifluoroacetic acid

Scheme 1.

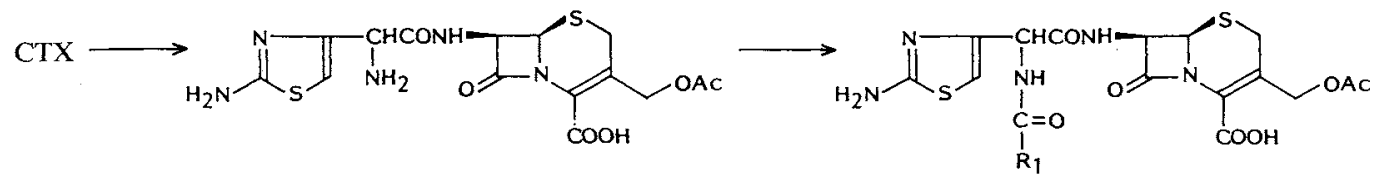

2

3

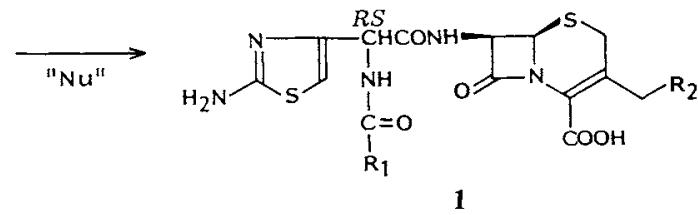

$R_{1}$ Monohydroxypyridone<smiles>Cc1ccc(O)c(=O)[nH]1</smiles><smiles>Cc1cc(=O)c(O)c[nH]1</smiles><smiles>Cc1c[nH]c(O)cc1=O</smiles><smiles>Cc1cc(O)[nH]c(=O)c1</smiles><smiles>Cc1ccc(=O)n(O)c1</smiles>

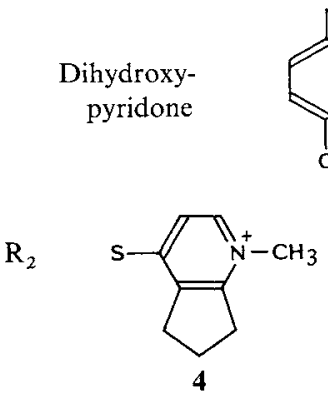<smiles>Cc1ccc(O)c(=O)n1O</smiles><smiles>Cc1cc(=O)c(O)cn1O</smiles>

f<smiles>CC1Cc2c(S)cc[n+](CC(=O)O)c2C1</smiles><smiles></smiles><smiles>OCC[n+]1ccc(S)cc1</smiles> 
Scheme 2.<smiles>COc1ccc(C(=O)OCC(C(=O)O)C(F)(F)F)nc1Cl</smiles>
8 9 10<smiles>O=c1cc(CO)occ1O</smiles>

12<smiles>O=c1cc(CO)occ1O[Mg]O[Na]</smiles>

13<smiles></smiles>

14<smiles>CCCCCCOc1cn(O)c(C(=O)O)cc1=O</smiles>

15<smiles>COc1ccc(C=[15NH])cc1</smiles>

to afford pyridine $N$-oxide 10. Hydrolysis and demethylation of $\mathbf{1 0}$ gave $\mathbf{1 1}$ in an overall yield of about $33 \%$ from 8 . Condensation of 11 with 2 by the DCC method was not accomplished without protecting the two hydroxyl groups of $\mathbf{1 1}$, but it was completed after protection of them with 2-methoxyethoxymethyl groups.

Compound 15 was prepared from kojic acid (12). Its phenolic hydroxyl group was protected by a p-methoxybenzyl group to afford 13, followed by oxidation with nickel peroxide ${ }^{9)}$ to give carboxylic acid 14. Compound $\mathbf{1 4}$ was treated with hydroxylamine hydrochloride in pyridine to convert it into $N$-hydroxypyridone 15 in an overall yield of $25 \%$ from 12 .

\section{Effects of Mono- and Dihydroxypyridone Moiety on the Antibacterial Activity}

The MICs of the new cephalosporins having mono- or dihydroxypyridonecarbonyl groups are listed in Tables 1, 2 and 3. Among monohydroxypyridone derivatives having an acetoxymethyl group at C-3, $\mathbf{3 a}$ and $\mathbf{3 b}$ showed potent activity against Gram-positive and Gram-negative bacteria including $P$. aeruginosa. 1,5-Dihydroxy-4-pyridone derivative (3g) exhibited stronger activity than $\mathbf{3 b}$ against Pseudomonas. 1,3-Dihydroxy-2-pyridone derivative (3f), however, was less active than 3a (Table 1).

As shown in Table 2, replacement of the C-3 acetoxymethyl group of anti-pseudomonal compounds 3 by the $N$-methylcyclopentano $[b]$ pyridiniumthiomethyl group improved the antibacterial activity against almost all the organisms tested. The effects of the pyridone moieties in compounds 4 were similar to those in 3. Among compounds $\mathbf{4}$, anti-pseudomonal activity of $\mathbf{4 b}$ and $\mathbf{4 g}$ were superior to that of ceftazidime.

Comparison of the biological activities of the compounds having a 5-hydroxy-4-pyridone-2-carbonyl group (type b) with those of the compounds bearing a 1,5-dihydroxy-4-pyridone-2-carbonyl group (type $\mathrm{g}$ ), as shown in Table 3 , demonstrated that type $\mathrm{g}$ compounds $(\mathbf{5 g}, \mathbf{6 g}$ and $7 \mathrm{~g}$ ) have activity superior to type b compounds (5b, 6b and $\mathbf{7 b}$ ) and catechol derivatives (16 and 17) against Pseudomonas and other Gram-negative bacteria. The activity of type $\mathbf{g}$ compounds against Gram-positive bacteria was approximately equal or somewhat inferior to that of type $\mathbf{b}$ compounds.

Concerning solubility in water, type $\mathbf{g}$ compounds were more soluble than type $\mathbf{b}$ compounds and were suitable as injectable drugs. For instance, the solubility of $6 \mathbf{g}$ was more than $30 \% \mathrm{w} / \mathrm{v}$, while that of 6b was less than $10 \% \mathrm{w} / \mathrm{v}$. 
Table 1. Antibacterial activity of compounds $\mathbf{3}$.<smiles>[R1]C(=O)NC(C(=O)N[C@H]1C(=O)N2C(C(=O)O)=C(COC(C)=O)CS[C@H]12)c1csc(N)n1</smiles>

3

$\operatorname{MIC}(\mu \mathrm{g} / \mathrm{ml})$

Test organism

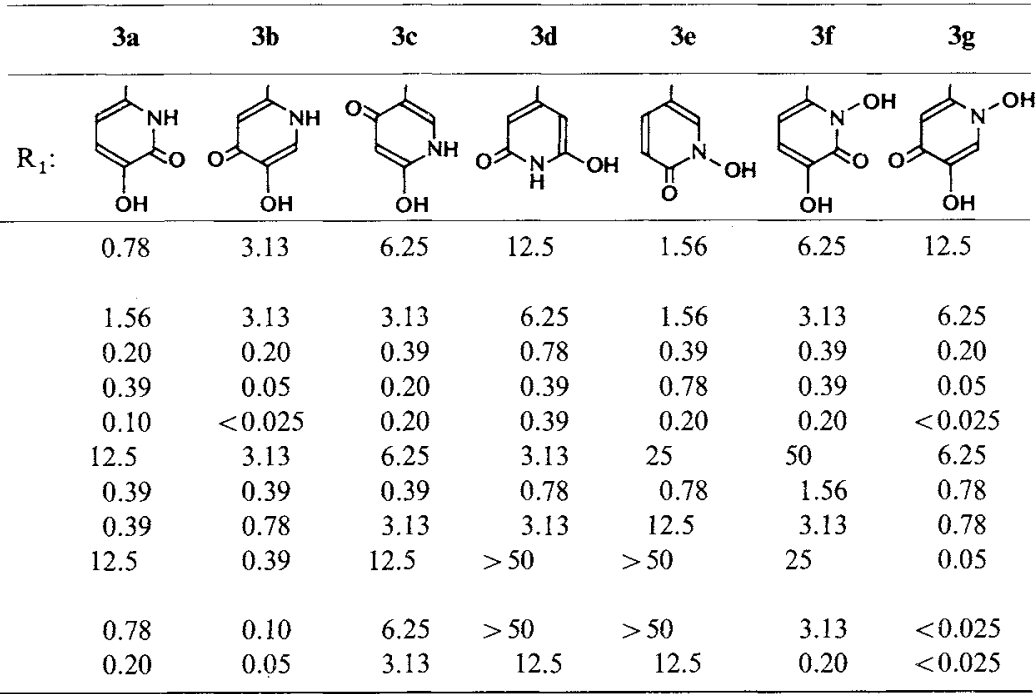

Staphylococcus aureus 209P JC-1

Bacillus subtilis ATCC 6633

Escherichia coli NIHJ JC-2

Klebsiella pneumoniae $\mathrm{GN} 69^{\mathrm{a}}$

$K$. pneumoniae PCI 602

Providencia rettgeri $\mathrm{GN} 624^{2}$

Enterobacter cloacae G-0008

Serratia marcescens No. 1

Pseudomonas aeruginosa

GN10362

$P$. aeruginosa $\mathrm{E}-2$

$P$. cepacia M-0527

a $\beta$-Lactamase-producing strain.

Table 2. Antibacterial activity of compounds 4 .

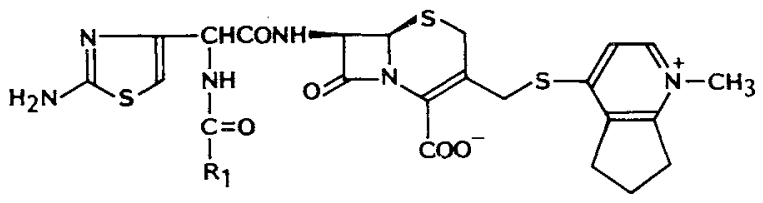

4

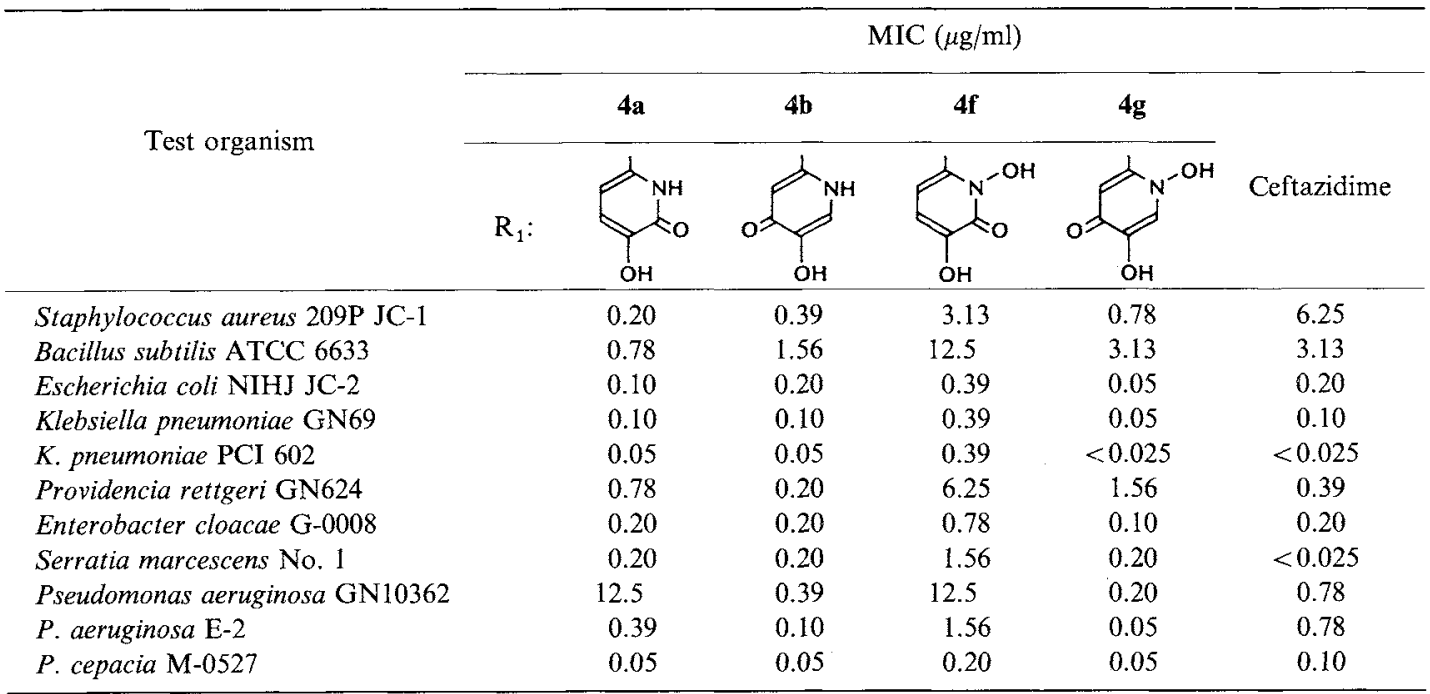


Table 3. Antibacterial activity of compounds 5, 6, 7, 16 and 17.

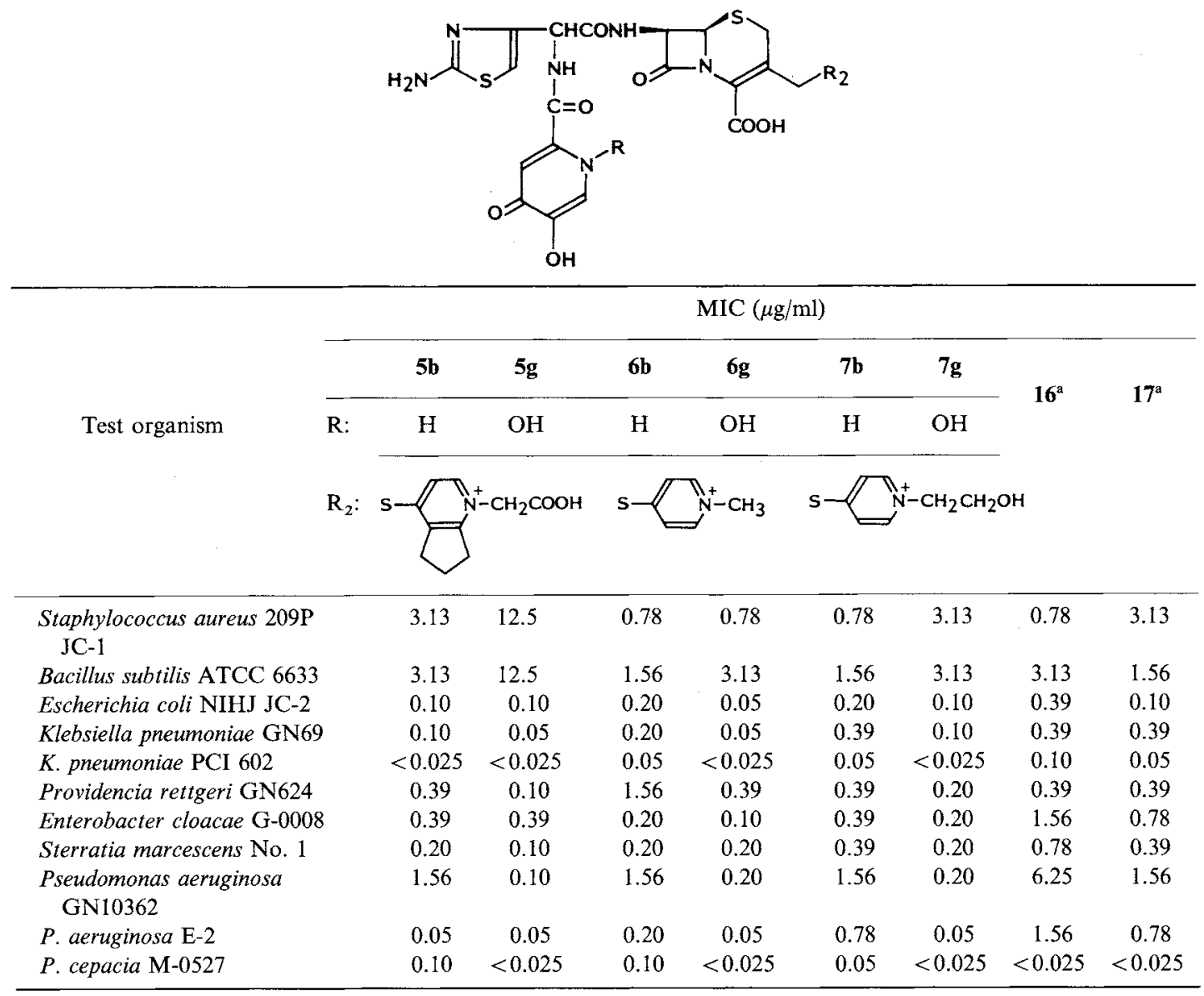

a $\mathrm{R}_{1}$ : Catechol moiety, $\mathrm{R}_{2}: 16 \mathrm{~s}-\mathrm{N}^{+}-\mathrm{CH}_{2} \mathrm{CH}_{2} \mathrm{OH}$ and $17 \mathrm{~s}-\mathrm{CH}_{2} \mathrm{COOH}$.

It was presumed that a hydroxyl group introduced at 1-N of the 5-hydroxy-4-pyridone-2-carbonyl group acted like an acidic substituent such as carboxyl group and this could contribute much to the increase in anti-pseudomonal activity and solubility in water. Thus, we selected the 1,5-dihydroxy-4pyridone-2-carbonyl group (type $\mathbf{g}$ ) as the preferred acyl moiety attached to the $\alpha$-amino group of the aminothiazolylglycyl side chain.

\section{Effects of C-3 Substituents on the Antibacterial Activity}

In a series of compounds having the 1,5-dihydroxy-4-pyridone-2-carbonyl group, effects of various substituents at C-3 on the antibacterial activity were examined. Among the derivatives $(\mathbf{1 8} \sim \mathbf{3 2})$ containing various heterocyclic thiomethyl groups, compounds 18, 19 (pyridyl), 23 (1,3,4-triazinyl), 25 (1,2,3-thiadiazolyl) and $\mathbf{3 1}$ (benzothiazolyl) had a well balanced activity against Gram-positive and Gram-negative bacteria, as shown in Table 4 . On the other hand, among the derivatives $(\mathbf{4 g} \sim 7 \mathbf{g}, \mathbf{3 3} \sim \mathbf{4 4})$ containing various $N$-alkylpyridiniumthiomethyl or pyridiniummethyl groups, compounds $4 \mathbf{4 g}, \mathbf{6 g}, \mathbf{7 g}, 38$, 40 and 44 with neutral substituents on the $1-\mathrm{N}$ of the pyridine nucleus showed more potent activity than others against Gram-negative bacteria including Pseudomonas, as shown in Tables 2, 3 and 5. Compounds 
Table 4. Antibacterial activity of compounds $18 \sim 32$.<smiles>[R2]CC1=C(C(=O)O)N2C(=O)[C@@H](NC(=O)C(NC(=O)c3cc(=O)c(O)cn3O)c3csc(N)n3)[C@H]2SC1</smiles>

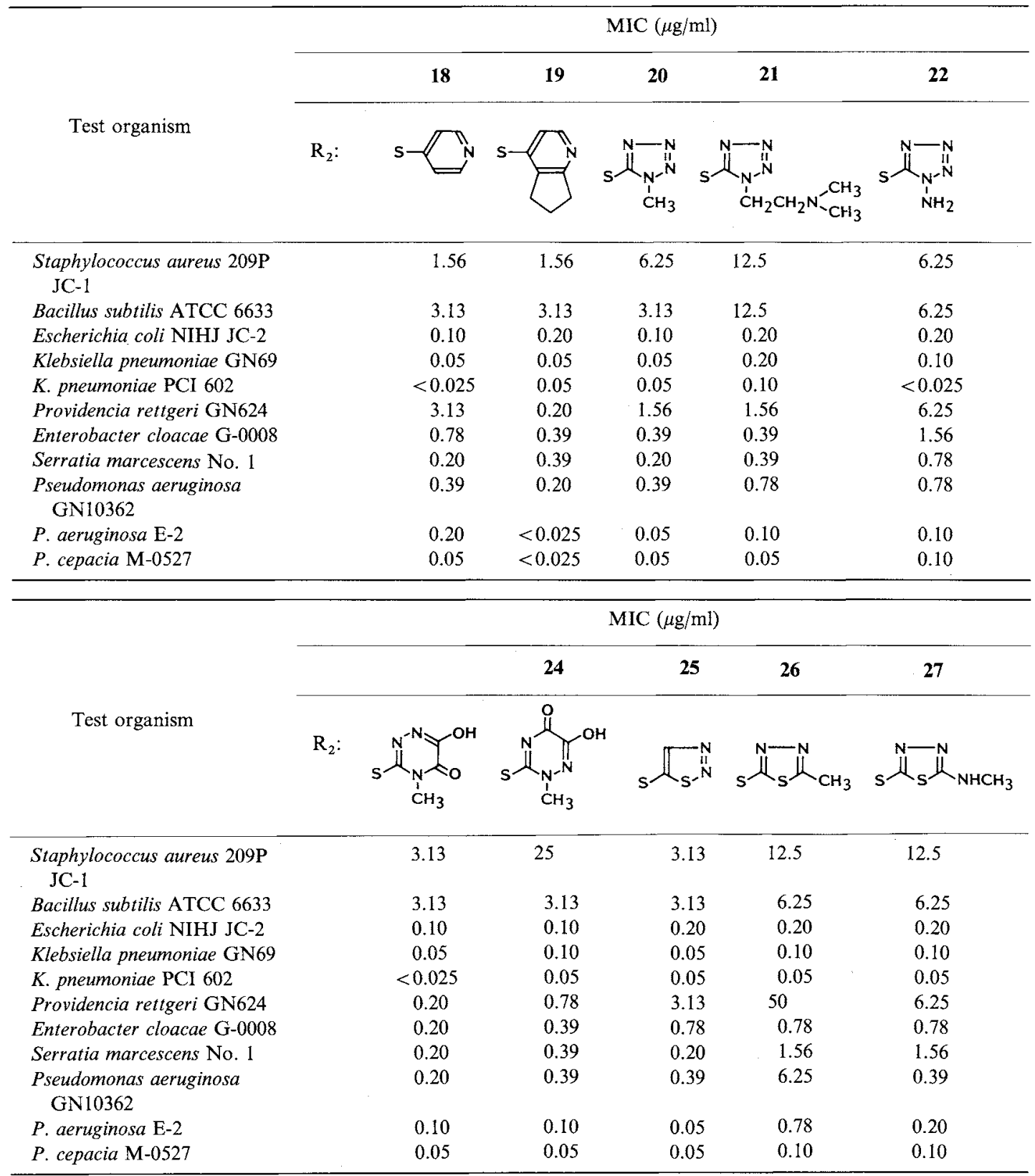


Table 4. (Continued)

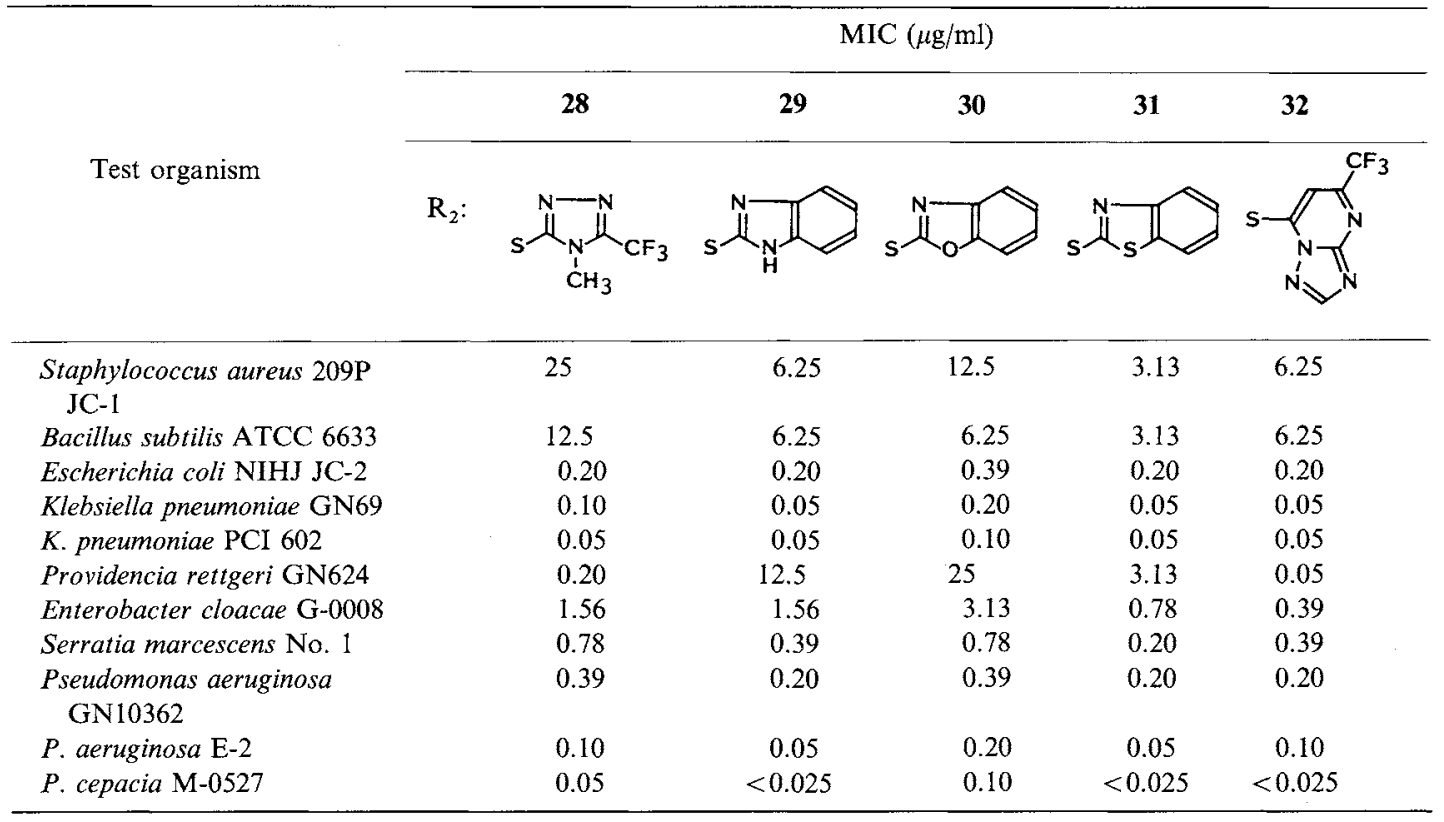

(33 36) bearing a pyridiniummethyl group showed inferior activity against most of Gram-negative bacteria to the derivatives with an $\mathrm{N}$-alkylpyridiniumthiomethyl group (Table 5). Introduction of an acidic substituent such as carboxymethyl (5g and 37) or sulfoethyl (43) group in the C-3 substituent reduced the activity against Gram-positive bacteria.

Among these derivatives, we selected some candidates $(\mathbf{4 g}, \mathbf{6 g}, 7 \mathrm{~g}, 19,25,31$ and $\mathbf{4 0})$ for further evaluation on the basis of anti-pseudomonal activity and solubility in water. The urinary recovery rates in mice by subcutaneous administration of the derivatives $(\mathbf{4 g}, \mathbf{6 g}, 7 \mathrm{~g}$ and $\mathbf{4 0}$ ) possessing an $N$-alkylpyridiniumthiomethyl group were $67 \sim 90 \%$ and higher than those of compounds $(\mathbf{1 9}, 25$ and 31$)$ with a heterocyclic thiomethyl group, as shown in Table 6. In comparison with $\mathbf{6 g}$ having an $N$-methylpyridiniumthiomethyl group, compound $\mathbf{4 g}$ having an $N$-methylcyclopentano[b]pyridiniumthiomethyl group showed a high urinary recovery rate but was less soluble in water and more toxic. Compounds $4 \mathrm{~g}, 19$ and 31 revealed toxicity at a dose of $2.0 \mathrm{~g} / \mathrm{kg}$ in mice after intravenous injection. However, no toxicity was observed for $7 \mathrm{~g}$ at a dose of $4.0 \mathrm{~g} / \mathrm{kg}$.

\section{Antibacterial Activity In Vivo}

The activities in vivo of 1,5-dihydroxy-4-pyridone derivatives $\mathbf{6 g}, \mathbf{7 g}$ and $\mathbf{4 0}$ are listed in Table 7. These three compounds were active in mice against an experimental infection with Escherichia coli GN206. Compound $7 \mathrm{~g}$ showed strong activity in vivo against the infection with $P$. aeruginosa GN10362 through only one administration as expected from the MIC value.

As shown in Table 8, the antibacterial activity in vivo of $\mathbf{7 g}$ (MT0703) against Gram-negative bacteria was compared with that of ceftazidime and cefoperazone. MT0703 showed strong activity in vivo against P. aeruginosa E-2 and GN10362, E. coli No. 29 and Klebsiella pneumoniae PCI 602 as well as in vitro, and was more potent than ceftazidime and cefoperazone in all of the infections tested.

Based on these results, MT0703 (7g), containing a [1-(2-hydroxyethyl)pyridinium-4-yl]thiomethyl group 
Table 5. Antibacterial activity of compounds $33 \sim 44$.<smiles>[R2]CC1=C(C(=O)O)N2C(=O)[C@@H](NC(=O)C(NC(=O)c3cc(=O)c(O)cn3O)c3csc(N)n3)[C@H]2SC1</smiles>

\begin{tabular}{|c|c|c|c|c|c|c|c|c|}
\hline \multirow{5}{*}{ Test organism } & \multicolumn{8}{|c|}{$\mathrm{MIC}(\mu \mathrm{g} / \mathrm{ml})$} \\
\hline & & 33 & 34 & 35 & 36 & 37 & 38 & 39 \\
\hline & & \multicolumn{3}{|c|}{$s-{ }^{+}-R_{3}$} \\
\hline & $\mathrm{n}:$ & 3 & 0 & 3 & 0 & \multirow[b]{2}{*}{$\mathrm{CH}_{2} \mathrm{COOH}$} & \multirow[b]{2}{*}{$\mathrm{CH}_{2} \mathrm{CONH}_{2}$} & \multirow[b]{2}{*}{$\mathrm{CH}_{2} \mathrm{CONHOH}$} \\
\hline & $\mathrm{R}_{3}$ : & $\mathrm{H}$ & $\mathrm{H}$ & $\mathrm{SCH}_{3}$ & $\mathrm{SCH}_{3}$ & & & \\
\hline $\begin{array}{l}\text { Staphylococcus aureus } 209 \mathrm{P} \\
\text { JC-1 }\end{array}$ & & 0.78 & 6.25 & 3.13 & 3.13 & 6.25 & 1.56 & 3.13 \\
\hline Bacillus subtilis ATCC 6633 & & 3.13 & 6.25 & 6.25 & 6.25 & 6.25 & 3.13 & 3.13 \\
\hline Escherichia coli NIHJ JC-2 & & 0.39 & 0.78 & 0.39 & 0.20 & 0.05 & 0.10 & 0.20 \\
\hline Klebsiella pneumoniae $\mathrm{GN} 69$ & & 0.39 & 0.39 & 0.39 & 0.20 & 0.10 & 0.10 & 0.20 \\
\hline K. pneumoniae PCI 602 & & 0.10 & 0.10 & 0.05 & 0.05 & $<0.025$ & $<0.025$ & 0.10 \\
\hline Providencia rettgeri GN624 & & 3.13 & 12.5 & 1.56 & 1.56 & 0.20 & 0.20 & 0.20 \\
\hline Enterobacter cloacae G-0008 & & 0.78 & 6.25 & 1.56 & 0.78 & 0.20 & 0.20 & 0.78 \\
\hline Serratia marcescens No. 1 & & 0.39 & 3.13 & 0.39 & 0.39 & 0.20 & 0.20 & 0.39 \\
\hline $\begin{array}{l}\text { Pseudomonas aeruginosa } \\
\text { GN10362 }\end{array}$ & & 0.78 & 1.56 & 1.56 & 0.78 & 0.20 & 0.20 & 1.56 \\
\hline P. aeruginosa $\mathrm{E}-2$ & & 0.10 & 0.20 & 0.20 & 0.10 & 0.05 & 0.05 & 0.20 \\
\hline P. cepacia M-0527 & & 0.10 & 0.10 & 0.05 & 0.10 & $<0.025$ & $<0.025$ & 0.10 \\
\hline \multirow{4}{*}{ Test organism } & \multicolumn{8}{|c|}{$\mathrm{MIC}(\mu \mathrm{g} / \mathrm{ml})$} \\
\hline & \multicolumn{3}{|c|}{40} & \multicolumn{2}{|c|}{41} & 42 & 43 & 44 \\
\hline & \multicolumn{5}{|l|}{$\mathbf{R}_{2}$} & $s-{ }_{N}^{+}-R_{3}$ & & \\
\hline & $\mathrm{R}_{3}$ & & & \multicolumn{2}{|c|}{$\mathrm{CH}_{2} \mathrm{CH}_{2} \mathrm{OH}^{\mathrm{a}}$} & $\mathrm{CH}_{2} \mathrm{CH}_{2} \mathrm{~F}$ & $\mathrm{CH}_{2} \mathrm{SO}_{3} \mathrm{H}$ & $\mathrm{CH}_{2} \mathrm{SO}_{2} \mathrm{NH}_{2}$ \\
\hline $\begin{array}{l}\text { Staphylococcus aureus 209P } \\
\text { JC-1 }\end{array}$ & \multicolumn{3}{|c|}{3.13} & \multicolumn{2}{|c|}{3.13} & 3.13 & 12.5 & 1.56 \\
\hline Bacillus subtilis ATCC 6633 & & & & \multicolumn{2}{|c|}{6.25} & 6.25 & 6.25 & 3.13 \\
\hline Escherichia coli NIHJ JC-2 & \multirow{2}{*}{\multicolumn{3}{|c|}{$\begin{array}{l}0.10 \\
0.10\end{array}$}} & \multicolumn{2}{|c|}{0.20} & 0.10 & 0.10 & 0.10 \\
\hline Klebsiella pneumoniae GN69 & & & & \multicolumn{2}{|c|}{0.05} & 0.10 & 0.10 & 0.05 \\
\hline K. pneumoniae PCI 602 & \multicolumn{3}{|c|}{$<0.025$} & \multirow{2}{*}{\multicolumn{2}{|c|}{$\begin{array}{l}0.05 \\
0.39\end{array}$}} & $<0.025$ & $<0.025$ & $<0.025$ \\
\hline Providencia rettgeri GN624 & \multicolumn{3}{|c|}{0.10} & & & 0.20 & 0.20 & 0.20 \\
\hline Enterobacter cloacae G-0008 & \multicolumn{3}{|c|}{0.20} & \multicolumn{2}{|c|}{0.39} & 0.20 & 0.20 & 0.20 \\
\hline Serratia marcescens No. 1 & \multicolumn{3}{|c|}{0.20} & \multicolumn{2}{|c|}{0.39} & 0.20 & 0.10 & 0.39 \\
\hline $\begin{array}{l}\text { Pseudomonas aeruginosa } \\
\text { GN10362 }\end{array}$ & \multicolumn{3}{|c|}{0.39} & & 39 & 0.20 & 0.20 & 0.39 \\
\hline P. aeruginosa $\mathrm{E}-2$ & & & 10 & & 10 & 0.10 & $<0.025$ & 0.05 \\
\hline P. cepacia M-0527 & & $<0$ & & $<0$. & 025 & 0.05 & $<0.025$ & $<0.025$ \\
\hline
\end{tabular}

a Pyridinium-3-yl. 
Table 6. Urinary excretion in mice.

\begin{tabular}{ccccccccc}
\hline Compound & $\mathbf{4 g}$ & $\mathbf{6 g}$ & $\mathbf{7 g}$ & $\mathbf{1 9}$ & $\mathbf{2 5}$ & $\mathbf{3 1}$ & $\mathbf{4 0}$ \\
\hline Urinary recovery $^{\mathrm{a}}(\%)$ & 90.2 & 79.1 & 67.2 & 10.2 & 29.9 & 11.3 & 77.2 \\
\hline
\end{tabular}

a After $25 \mathrm{mg} / \mathrm{kg}$ injection subcutaneously.

Table 7. Therapeutic efficacy in experimental infections in mice.

\begin{tabular}{|c|c|c|c|c|}
\hline Test organism & $\begin{array}{l}\text { Challenge dose } \\
{\text { (cfu/mouse })^{\mathrm{a}}}^{\text {(cfule }}\end{array}$ & Compound ${ }^{\mathbf{b}}$ & $\begin{array}{c}\mathrm{ED}_{50} \\
(\mathrm{mg} / \mathrm{kg})\end{array}$ & $\begin{array}{c}\mathrm{MIC} \\
(\mu \mathrm{g} / \mathrm{ml})\end{array}$ \\
\hline \multirow[t]{4}{*}{ Escherichia coli $\mathrm{GN} 206^{\mathrm{c}}$} & $9.5 \times 10^{6}$ & $6 \mathrm{~g}$ & 13.5 & 0.05 \\
\hline & & $7 \mathrm{~g}$ & 6.0 & 0.20 \\
\hline & & 40 & 6.5 & 0.20 \\
\hline & & Ceftazidime & $>50$ & 1.56 \\
\hline \multirow[t]{4}{*}{ Pseudomonas aeruginosa $\mathrm{GN} 10362^{\mathrm{c}}$} & $8.8 \times 10^{5}$ & $6 \mathrm{~g}$ & $>200$ & 0.20 \\
\hline & & $7 g$ & 145 & 0.20 \\
\hline & & 40 & $>200$ & 0.39 \\
\hline & & Ceftazidime & $>400$ & 1.56 \\
\hline
\end{tabular}

I Intraperitoneally.

b Subcutaneously.

c $\beta$-Lactamase-producing strain.

Table 8. Therapeutic efficacy of MT0703 (7g) and other cephalosporins in systemic infections in mice.

\begin{tabular}{|c|c|c|c|c|}
\hline Test organism & $\begin{array}{l}\text { Challenge dose } \\
(\mathrm{cfu} / \mathrm{mouse})^{\mathrm{a}}\end{array}$ & Compound ${ }^{b, c}$ & $\begin{array}{c}\mathrm{ED}_{50} \\
(\mathrm{mg} / \mathrm{kg})\end{array}$ & $\begin{array}{c}\mathrm{MIC} \\
(\mu \mathrm{g} / \mathrm{ml})\end{array}$ \\
\hline \multirow[t]{2}{*}{ Escherichia coli No. 29} & $3.5 \times 10^{6}$ & MT0703 & 0.4 & 0.05 \\
\hline & & Ceftazidime & 1.8 & 0.10 \\
\hline \multirow[t]{2}{*}{ Klebsiella pneumoniae PCI 602} & $4.4 \times 10^{3}$ & MT0703 & 0.3 & $<0.025$ \\
\hline & & Ceftazidime & 9.2 & $<0.025$ \\
\hline \multirow[t]{3}{*}{ Pseudomonas aeruginosa $\mathrm{E}-2$} & $5.2 \times 10^{6}$ & MT0703 & 12.5 & 0.05 \\
\hline & & Ceftazidime & 76 & 0.78 \\
\hline & & Cefoperazone & $>400$ & 3.13 \\
\hline \multirow[t]{3}{*}{$P$. aeruginosa GN10362d } & $6.8 \times 10^{5}$ & MT0703 & 12 & 0.20 \\
\hline & & Ceftazidime & 40.5 & 0.78 \\
\hline & & Cefoperazone & $>400$ & 6.25 \\
\hline
\end{tabular}

a Intraperitoneally.

b Subcutaneously.

c Administration: 1 and 3 hours after infections with $P$. aeruginosa.

d $\beta$-Lactamase-producing strain.

at C-3, was found to have excellent antibacterial activity, especially against Pseudomonas, and the most favorable solubility, pharmacokinetics and low toxicity among the candidates.

\section{The Stability to COMT}

As the type $\mathbf{g}$ acyl moiety is able to exist as dihydroxypyridone (19) and dihydroxypyridine $\mathrm{N}$-oxide $\left(\mathbf{l g}^{\prime}\right)$ tautomers as shown in Scheme 3, we think it is a catechol analogue. By enzymatic reaction with COMT for 2 hours, $18 \%$ of 17 , which has a 3,4-dihydroxybenzoyl group, was $O$-methylated. However, type $\mathbf{g}$ compounds $\mathbf{7 g}$ and 37 were not methylated. This suggests that the 1,5-dihydroxy-4-pyridone-2carbonyl group at the $\alpha$-amino group of the aminothiazolylglycyl side chain is stable to COMT and contributes to the potent antibacterial activity against Pseudomonas strains. 
Scheme 3.<smiles>[R2]CC1=C(C(=O)O)N2C(=O)[C@@H](NC(=O)C(NC(=O)c3cc(=O)c(O)cn3O)c3csc(N)n3)C2SC1</smiles>

$1 \mathrm{~g}$<smiles>[R2]CC1=C(C(=O)O)N2C(=O)[C@H](NC(=O)Cc3csc(N)n3)[C@H]2SC1</smiles>

$1 g^{\prime}$

Experimental

NMR spectra were recorded at $60 \mathrm{MHz}$ on a Varian T-60A NMR spectrometer and at $400 \mathrm{MHz}$ on a Jeol GX-400 NMR spectrometer using TMS as an internal standard. All chemical shifts are reported in $\delta$ ppm. IR spectra were recorded on a Jasco A-202 IR spectrophotometer. MS were taken on a Hitachi M-80B mass spectrometer (mainly SI-MS).

\section{Biological Evaluation}

$\overline{\mathrm{MICs}}(\mu \mathrm{g} / \mathrm{ml})$ were determined by the 2 -fold agar dilution method using sensitivity disk agar (Nissui Seiyaku, Co., Ltd.) after incubation at $37^{\circ} \mathrm{C}$ for 20 hours with an inoculum size of about $10^{6} \mathrm{cfu} / \mathrm{ml}$.

Antibacterial activity in vivo was tested using male mice (Jcl: ICR, 4 weeks old). Each of eight mice in a group was challenged intraperitoneally with $10^{3}$ to $10^{6} \mathrm{cfu}$ of the bacteria suspended in $0.5 \mathrm{ml}$ of saline containing $2.5 \%$ gastric mucin (Difco Laboratories). The animals were treated subcutaneously with test compounds 1 hour after challenge. $\mathrm{ED}_{50}$ values $(\mathrm{mg} / \mathrm{kg})$ were calculated by the probit method from the number of mice surviving 7 days after infection.

Urinary excretion was tested using male mice (Jcl:ICR, 4 weeks old). The test compounds were administered subcutaneously to three mice at a dose of $25 \mathrm{mg} / \mathrm{kg}$. Urinary recovery rates $(\%)$ were calculated from the urinary concentrations of drugs at 0 to 4 hours after administration. Concentrations were determined by bioassay using E. coli K-12 HW8236 as a test organism.

The acute toxicity was determined by the survival rate of male mice (Jcl: ICR, 5 weeks old, three per group) 2 weeks after intravenous injection of the test compounds.

\section{Enzymatic Reaction with COMT}

To a solution of $0.2 \mathrm{ml}$ of substrate $(7 \mathrm{~g}, 17$ or $37,1 \mathrm{mg} / \mathrm{ml}), 0.2 \mathrm{ml}$ of $1 \mathrm{~mm} S$-adenosylmethionine, $0.2 \mathrm{ml}$ of $1 \mathrm{mM} \mathrm{MgCl}_{2}$ and $0.2 \mathrm{ml}$ of $0.05 \mathrm{M}$ phosphate buffer $(\mathrm{pH} 7.9$ ) was added $0.2 \mathrm{ml}$ of porcine liver $\operatorname{COMT}(500 \mathrm{U} / \mathrm{ml}$, Sigma). All materials were dissolved in $0.05 \mathrm{~m}$ phosphate buffer at $\mathrm{pH} 7.9$ and the mixture was incubated at $37^{\circ} \mathrm{C}$ with gentle shaking. Since compound $\mathbf{1 6}$ was insoluble in the phosphate buffer at $\mathrm{pH} 7.9$, its activity could not be tested. The methylation was monitored by HPLC (column: Cosmosil $5 \mathrm{C}_{18}, 4.6$ i.d. $\times 150 \mathrm{~mm}$ (Nacalai Tesque, Inc.), mobile phase: $0.05 \mathrm{M} \mathrm{NH}_{4} \mathrm{H}_{2} \mathrm{PO}_{4}-\mathrm{CH}_{3} \mathrm{CN}-\mathrm{MeOH}$ (85: 10:5, $\mathrm{pH} 2.5)$, UV detection at $305 \mathrm{~nm}, 29^{\circ} \mathrm{C}$ ).

\section{3-Hydroxy-2-pyridone-6-carboxylic Acid (8)}

To a suspension of potassium salt of D-glucaro-1,5-1actam $\left.{ }^{8}\right)(60 \mathrm{~g})$ in $500 \mathrm{ml}$ of pyridine was added $250 \mathrm{ml}$ of acetic anhydride, and the reaction mixture was stirred at $70 \sim 75^{\circ} \mathrm{C}$ for 4 days. The insoluble product was collected by filtration, washed with ether, crystallized from $\mathrm{H}_{2} \mathrm{O}$ and dried to afford 3-acetoxy-2-pyridone-6-carboxylic acid as the potassium salt $(52 \mathrm{~g})$. A mixture of the potassium salt $(52 \mathrm{~g})$ and $\mathrm{NaOH}(30 \mathrm{~g})$ in $500 \mathrm{ml}$ of $\mathrm{H}_{2} \mathrm{O}$ was stirred at $60^{\circ} \mathrm{C}$ for 20 minutes and acidified to $\mathrm{pH} 1.8$ with $5 \mathrm{~N}$ $\mathrm{HCl}$. The crystals were collected by filtration and dried to afford $8(31 \mathrm{~g}, 76 \%)$ : IR $(\mathrm{KBr}) \mathrm{cm}^{-1} 3060$, $1685,1630,1610,1555,1285 ;{ }^{1} \mathrm{H}$ NMR $\left(\mathrm{DMSO}-d_{6}\right) \delta 6.73(1 \mathrm{H}, \mathrm{d}), 6.90(1 \mathrm{H}, \mathrm{d}), 9.97(1 \mathrm{H}, \mathrm{br} \mathrm{s})$; EI-MS $m / z 155\left(\mathrm{M}^{+}\right)$.

$$
\begin{array}{ll}
\text { Anal Calcd for } \mathrm{C}_{6} \mathrm{H}_{5} \mathrm{NO}_{4}: & \mathrm{C} 46.46, \mathrm{H} 3.25, \mathrm{~N} 9.03 . \\
\begin{array}{ll}
\text { Found: } & \text { C 46.48, H 3.19, N 8.96. }
\end{array}
\end{array}
$$


6-Carboxy-2-chloro-3-methoxypyridine $N$-Oxide (10)

(a): To a solution of $8(31 \mathrm{~g})$ and $\mathrm{K}_{2} \mathrm{CO}_{3}(55.2 \mathrm{~g})$ in $500 \mathrm{ml}$ of $\mathrm{H}_{2} \mathrm{O}$ were added dioxane $(150 \mathrm{ml})$ and $\mathrm{CH}_{3} \mathrm{I}(50 \mathrm{ml})$. The reaction mixture was stirred at $70^{\circ} \mathrm{C}$ for 7 hours and the precipitate was collected. The precipitate was dissolved in water and acidified to $\mathrm{pH} 1.5$ with $6 \mathrm{~N} \mathrm{HCl}$. The crystals were collected by filtration, washed with $\mathrm{H}_{2} \mathrm{O}$ and dried to give 3-methoxy-2-pyridone-6-carboxylic acid $(25 \mathrm{~g}, 74 \%)$ : ${ }^{1} \mathrm{H}$ NMR (DMSO- $\left.d_{6}\right) \delta 3.77(3 \mathrm{H}, \mathrm{s}), 6.83(1 \mathrm{H}, \mathrm{d}), 6.96(1 \mathrm{H}, \mathrm{d})$.

3-Methoxy-2-pyridone-6-carboxylic acid ( $16.9 \mathrm{~g}$ ) was suspended in $150 \mathrm{ml}$ of phosphoryl chloride, and the reaction mixture was refluxed for 20 hours. The precipitate was filtered off and the filtrate was evaporated. To the residue was added ice-water. After this mixture had been stirred for 1 hour, the product formed was collected by filtration, dissolved in $\mathrm{H}_{2} \mathrm{O}$ at $\mathrm{pH} 10$ and treated with charcoal. The charcoal was filtered off and the filtrate was acidified to $\mathrm{pH} 2$ with $5 \mathrm{~N} \mathrm{HCl}$. The crystals were collected by filtration and recrystallized from a mixture of $\mathrm{CHCl}_{3}$ and $\mathrm{MeOH}$ to afford 2-chloro-3-methoxy-6-pyridinecarboxylic acid (9) $(15 \mathrm{~g}, 80 \%):{ }^{1} \mathrm{H}$ NMR (DMSO- $\left.d_{6}\right) \delta 3.95(3 \mathrm{H}, \mathrm{s}), 7.64(1 \mathrm{H}, \mathrm{d}), 8.05(1 \mathrm{H}, \mathrm{d}) ;$ FD-MS $m / z 188$ $(\mathrm{M}+\mathrm{H})^{+}$.

(b): To a solution of $9(14.8 \mathrm{~g})$ in $150 \mathrm{ml}$ of TFA was added $75 \mathrm{ml}$ of $30 \%$ hydrogen peroxide. The reaction mixture was stirred at $80^{\circ} \mathrm{C}$ for 2 hours and concentrated under reduced pressure. To the residue was added $45 \mathrm{ml}$ of $\mathrm{MeOH}$. The crystals were collected by filtration and dried to afford $10(15.6 \mathrm{~g}, 97 \%)$ : IR $(\mathrm{KBr}) \mathrm{cm}^{-1} 1705,1590,1470,1370,1240,1075 ;{ }^{1} \mathrm{H}$ NMR (DMSO- $\left.d_{6}\right) \delta 4.06(3 \mathrm{H}, \mathrm{s}), 7.66(1 \mathrm{H}, \mathrm{d})$, $8.23(1 \mathrm{H}, \mathrm{d}) ; \mathrm{SI}-\mathrm{MS} m / 2204(\mathrm{M}+\mathrm{H})^{+}$.

\section{1,3-Dihydroxy-2-pyridone-6-carboxylic Acid (11)}

To the suspension of $10(15.5 \mathrm{~g})$ in $100 \mathrm{ml}$ of $\mathrm{H}_{2} \mathrm{O}$ was added $28.56 \mathrm{~g}$ of $\mathrm{NaOH}$, and the mixture was refluxed for 1.5 hours. The mixture was cooled with an ice bath and acidified to $\mathrm{pH} 1.5$ with conc $\mathrm{HCl}$. The crystals were collected by filtration, washed with ice-water and hot $\mathrm{MeOH}$, and dried to give 1-hydroxy-3-methoxy-2-pyridone-6-carboxylic acid (14.9 g): ${ }^{1} \mathrm{H}$ NMR (DMSO- $\left.d_{6}\right) \delta 3.75(3 \mathrm{H}, \mathrm{s}), 6.76(1 \mathrm{H}$, d), $6.85(1 \mathrm{H}, \mathrm{d})$; FD-MS $m / z 185\left(\mathrm{M}^{+}\right)$.

To a suspension of 1-hydroxy-3-methoxy-2-pyridone-6-carboxylic acid $(3.16 \mathrm{~g})$ in $100 \mathrm{ml}$ of 1,2-dichloroethane was added $12 \mathrm{ml}$ of $\mathrm{N}, \mathrm{O}$-bis(trimethylsilyl)trifluoroacetamide (BSTFA). After the reaction mixture had been stirred at room temperature for 1.5 hours, $7.2 \mathrm{ml}$ of trimethylsilyl iodide (TMSI) was added. The reaction mixture was stirred at $50^{\circ} \mathrm{C}$ for 48 hours and diluted with $100 \mathrm{ml}$ of $\mathrm{CH}_{2} \mathrm{Cl}_{2}$. After addition of $4 \mathrm{ml}$ of ice-water, the mixture was stirred for 15 minutes. The precipitate was collected by filtration, washed with $\mathrm{CH}_{2} \mathrm{Cl}_{2}, \mathrm{Me}_{2} \mathrm{CO}$ and ice-water successively and dried to afford $11(1.61 \mathrm{~g}, 58 \%$ from 10): $\mathrm{IR}(\mathrm{KBr}) \mathrm{cm}^{-1} 3390,2800,1685,1620,1560,1460,1280 ;{ }^{1} \mathrm{H} \mathrm{NMR}\left(\mathrm{D}_{2} \mathrm{O}+\mathrm{NaHCO}_{3}\right) \delta 6.87$ $(1 \mathrm{H}, \mathrm{d}), 7.09(1 \mathrm{H}, \mathrm{d})$; FD-MS $m / z 171\left(\mathrm{M}^{+}\right)$.

Anal Calcd for $\mathrm{C}_{6} \mathrm{H}_{5} \mathrm{NO}_{5} \cdot \frac{1}{2} \mathrm{H}_{2} \mathrm{O}: \quad \mathrm{C} 40.01, \mathrm{H} 3.63, \mathrm{~N} 7.78$.

Found:

C 40.90, H 3.40, N 7.77 .

\section{5-( $p$-Methoxybenzyloxy)-4-pyrone-2-carboxylic Acid (14)}

To a suspension of kojic acid (12) (42.6g) and $\mathrm{K}_{2} \mathrm{CO}_{3}(82.8 \mathrm{~g})$ in $350 \mathrm{ml}$ of DMF was added dropwise $55.0 \mathrm{~g}$ of $p$-methoxybenzyl chloride at $70^{\circ} \mathrm{C}$. The reaction mixture was stirred for 1.5 hours at $75^{\circ} \mathrm{C}$ and concentrated under reduced pressure. The residue was poured over ice-water, and the precipitate was collected, washed with $\mathrm{H}_{2} \mathrm{O}$ and EtOAc, and dried to give 2-hydroxymethyl-5-(p-methoxybenzyloxy)-4pyrone (13) as colorless crystals $(61.6 \mathrm{~g}, 78 \%)$ : ${ }^{1} \mathrm{H}$ NMR (DMSO- $\left.d_{6}\right) \delta 3.80(3 \mathrm{H}, \mathrm{s}), 4.43(2 \mathrm{H}, \mathrm{s}), 4.96$ $(2 \mathrm{H}, \mathrm{s}), 6.50(1 \mathrm{H}, \mathrm{s}), 6.88(2 \mathrm{H}, \mathrm{d}), 7.30(2 \mathrm{H}, \mathrm{d}), 7.51(1 \mathrm{H}, \mathrm{s})$.

To a solution of $13(26.2 \mathrm{~g})$ in a mixture of THF $(125 \mathrm{ml}), \mathrm{H}_{2} \mathrm{O}(62.5 \mathrm{ml})$ and $1 \mathrm{~N} \mathrm{NaOH}(125 \mathrm{ml})$ was added $78 \mathrm{~g}$ of nickel peroxide at $0^{\circ} \mathrm{C}$, and the mixture was stirred at $10 \sim 15^{\circ} \mathrm{C}$ for 2.5 hours. The insoluble material was filtered off, and the filtrate was concentrated and acidified to $\mathrm{pH} 2$ with $6 \mathrm{~N} \mathrm{HCl}$. The crystalline product was collected, washed with $\mathrm{H}_{2} \mathrm{O}$ and $\mathrm{CHCl}_{3}$, and dried to afford $14(20.5 \mathrm{~g}, 74 \%)$ : IR $(\mathrm{KBr}) \mathrm{cm}^{-1}$ $3400,2850,1720,1610,1580,1550,1250,1210 ;{ }^{1} \mathrm{H}$ NMR (DMSO- $\left.d_{6}\right) \delta 3.77(3 \mathrm{H}, \mathrm{s}), 4.90(2 \mathrm{H}, \mathrm{s}), 6.92$ $(1 \mathrm{H}, \mathrm{s}), 6.96(2 \mathrm{H}, \mathrm{d}), 7.37(2 \mathrm{H}, \mathrm{d}), 8.34(1 \mathrm{H}, \mathrm{s})$; FD-MS $m / z 276\left(\mathrm{M}^{+}\right)$.

1-Hydroxy-5-( $p$-methoxybenzyloxy)-4-pyridone-2-carboxylic Acid (15)

A mixture of $14(10.35 \mathrm{~g})$ and hydroxylamine hydrochloride $(13 \mathrm{~g})$ in $150 \mathrm{ml}$ of pyridine was stirred 
at $75^{\circ} \mathrm{C}$ for 1.5 hours. The reaction mixture was cooled and evaporated. The residue was dissolved in water and acidified to $\mathrm{pH} 2.0 \sim 2.5$ with $4 \mathrm{~N} \mathrm{HCl}$ at $0^{\circ} \mathrm{C}$. The precipitate was collected, washed with $\mathrm{H}_{2} \mathrm{O}$ and dried to afford $15(4.7 \mathrm{~g}, 43 \%)$ : IR $(\mathrm{KBr}) \mathrm{cm}^{-1} 3430,1610,1530,1515,1380,1290,1240 ;{ }^{1} \mathrm{H}$ NMR $\left(\mathrm{DMSO}-d_{6}\right) \delta 3.80(3 \mathrm{H}, \mathrm{s}), 5.22(2 \mathrm{H}, \mathrm{s}), 7.00(2 \mathrm{H}, \mathrm{d}), 7.43(2 \mathrm{H}, \mathrm{d}), 7.59(1 \mathrm{H}, \mathrm{s}), 8.59(1 \mathrm{H}, \mathrm{s})$; FD-MS $\mathrm{m} / \mathrm{z}$ $292(\mathrm{M}+\mathrm{H})^{+}$.

Anal Calcd for $\mathrm{C}_{14} \mathrm{H}_{13} \mathrm{NO}_{6}$ : C $57.73, \mathrm{H} 4.50, \mathrm{~N} 4.81$.

Found: $\quad$ C $57.27, \mathrm{H} 4.39, \mathrm{~N} 4.70$.

General Procedure for the Acylation of 2

Method A: To a solution of $1 \mathrm{mmol}$ of 2 in a mixture of $5 \mathrm{ml}$ of THF and $5 \mathrm{ml}$ of $\mathrm{H}_{2} \mathrm{O}$ at $\mathrm{pH} 8$ adjusted with $\mathrm{Et}_{3} \mathrm{~N}$ was added 1.1 to $1.2 \mathrm{mmol}$ of acid chloride or active ester of mono- or dihydroxypyridonecarboxylic acid at $0^{\circ} \mathrm{C}$. The reaction mixture was stirred at $0^{\circ} \mathrm{C}$ for 2 hours, adjusted to $\mathrm{pH} 6.5$, evaporated to remove THF and acidified to $\mathrm{pH} 2$ with $1 \mathrm{~N} \mathrm{HCl}$. The residue was purified by column chromatography on Diaion HP-20 eluted with aq $\mathrm{Me}_{2} \mathrm{CO}$ to give 3 . When the phenolic hydroxyl group was protected, removal of protecting group was accomplished with TFA in anisole. The product was dissolved in $10 \%$ aq $\mathrm{NaHCO}_{3}$ after being adjusted to $\mathrm{pH} 7.0 \sim 7.5$, and was chromatographed on Diaion HP-20 eluted with $50 \%$ aq $\mathrm{MeOH}$ to afford 3 as the sodium salt.

Method B: To a solution of $1 \mathrm{mmol}$ of 2 and $1.2 \mathrm{mmol}$ of $\mathrm{Et}_{3} \mathrm{~N}$ in $8 \mathrm{ml}$ of DMF was added $1.2 \mathrm{mmol}$ of active ester of mono- or dihydroxypyridonecarboxylic acid at $0^{\circ} \mathrm{C}$. The reaction mixture was stirred at room temperature for 2.5 hours and evaporated under reduced pressure. The product was purified by a similar procedure to that described in Method A to obtain 3.

The IR, mass and ${ }^{1} \mathrm{H}$ NMR data for compounds 3 are listed in Table 9.

$(6 R, 7 R)-7-[(R S)$-2-(2-Aminothiazol-4-yl)-2-(1,3-dihydroxy-2-pyridone-6-carboxamido)acetamido]3-(acetoxymethyl)ceph-3-em-4-carboxylic Acid (3f)

(a): To a solution of $1.344 \mathrm{~g}$ of 11 in $20 \mathrm{ml}$ of DMF was added $1.2 \mathrm{~g}$ of $60 \%$ sodium hydride at $0^{\circ} \mathrm{C}$, and the mixture was stirred for 30 minutes. To the reaction solution was added $3.5 \mathrm{ml}$ of 2-methoxyethoxymethyl chloride at $0^{\circ} \mathrm{C}$. The reaction mixture was stirred at room temperature for 3 hours. After addition of $\mathrm{MeOH}(0.5 \mathrm{ml})$, the reaction mixture was diluted with EtOAc, washed with $\mathrm{H}_{2} \mathrm{O}$, dried over $\mathrm{MgSO}_{4}$ and evaporated under reduced pressure. The residue was purified on silica gel column chromatography with $\mathrm{CHCl}_{3}-\mathrm{MeOH}(100: 3)$, to afford 2-methoxyethoxymethyl 1,3-bis(2-methoxyethoxymethoxy)-2-pyridone-6-carboxylate $(1.867 \mathrm{~g}, 54 \%):{ }^{1} \mathrm{H} \mathrm{NMR}\left(\mathrm{CDCl}_{3}\right) \delta 3.38(9 \mathrm{H}$, br s), $3.4 \sim 3.65(6 \mathrm{H})$, $3.7 \sim 4.1(6 \mathrm{H}), 5.34(4 \mathrm{H}, \mathrm{s}), 5.52(2 \mathrm{H}, \mathrm{s}), 6.76(1 \mathrm{H}, \mathrm{d}), 7.00(1 \mathrm{H}, \mathrm{d})$.

To a solution of $1.25 \mathrm{~g}$ of 2-methoxyethoxymethyl 1,3-bis(2-methoxyethoxymethoxy)-2-pyridone-6carboxylate in a mixture of THF $(4 \mathrm{ml})$ and $\mathrm{MeOH}(1 \mathrm{ml})$ was added $1 \mathrm{~N} \mathrm{NaOH}(4 \mathrm{ml})$. The mixture was stirred at room temperature for 1 hour and evaporated under reduced pressure. To the residue was added brine, and the mixture was adjusted to $\mathrm{pH} 2$ and extracted with $\mathrm{CH}_{2} \mathrm{Cl}_{2}$. The extract was dried over $\mathrm{MgSO}_{4}$ amd Molecular Sieves 4A, and evaporated to give 1,3-bis(2-methoxyethoxymethoxy)-2-pyridone-6carboxylic acid $(865 \mathrm{mg}, 87 \%):{ }^{1} \mathrm{H}$ NMR $\left(\mathrm{CDCl}_{3}\right) \delta 3.37(6 \mathrm{H}, \mathrm{s}), 3.43 \sim 3.68(4 \mathrm{H}), 3.7 \sim 4.2(4 \mathrm{H}), 5.38$ $(4 \mathrm{H}, \mathrm{s}), 6.85(1 \mathrm{H}, \mathrm{d}), 7.07(1 \mathrm{H}, \mathrm{d})$.

(b): To a solution of $392 \mathrm{mg}$ of the product obtained in (a) in a mixture of $\mathrm{CH}_{2} \mathrm{Cl}_{2}(3 \mathrm{ml})$ and $\mathrm{DMF}$ ( $1 \mathrm{ml}$ ) were added $245 \mathrm{mg}$ of DCC and $153 \mathrm{mg}$ of 1 -hydroxybenzotriazole. The mixture was stirred at room temperature for 1 hour and filtered. The filtrate was added to a mixture of the $\mathrm{HCl}$ salt of $2(577 \mathrm{mg})$ and $\mathrm{Et}_{3} \mathrm{~N}(0.26 \mathrm{ml})$ in DMF $(6 \mathrm{ml})$. The reaction mixture was stirred at room temperature for 2.5 hours and evaporated under reduced pressure. The residue was purified by column chromatography on Diaion HP-20 to give $(6 R, 7 R)-7-[(R S)$-2-(2-aminothiazol-4-yl)-2-[1,3-bis(2-methoxyethoxymethoxy)-2-pyridone-6-carboxamido]acetamido]-3-(acetoxymethyl)ceph-3-em-4-carboxylic acid as the $\mathrm{Et}_{3} \mathrm{~N}$ salt $(483 \mathrm{mg}, 49 \%):{ }^{1} \mathrm{H}$ NMR $\left(\mathrm{D}_{2} \mathrm{O}\right) \delta 1.29(9 \mathrm{H}, \mathrm{t}), 2.11(3 \mathrm{H}, \mathrm{s}), 3.22(6 \mathrm{H}, \mathrm{q}), 3.31(3 \mathrm{H}), 3.34(3 \mathrm{H}, \mathrm{s}), 3.3 \sim 3.9(10 \mathrm{H}), 4.65 \sim 4.95$ $(2 \mathrm{H}), 5.13$ and $5.17(1 \mathrm{H}, \mathrm{d}), 5.30(1 \mathrm{H}), 5.42(4 \mathrm{H}), 5.65(1 \mathrm{H}), 6.81 \sim 6.9(2 \mathrm{H}), 7.26(1 \mathrm{H}, \mathrm{d})$.

(c): To a suspension of $465 \mathrm{mg}$ of the product obtained in (b) in $2 \mathrm{ml}$ of anisole was added $4 \mathrm{ml}$ of TFA at $0^{\circ} \mathrm{C}$ and the reaction mixture was stirred from $0^{\circ} \mathrm{C}$ to room temperature for 4.5 hours, and poured into $60 \mathrm{ml}$ of isopropyl ether. The precipitate was collected by filtration and dissolved in $10 \%$ aq $\mathrm{NaHCO}_{3}$ after being adjusted to $\mathrm{pH} 7.5$, and chromatographed on Diaion HP-20 eluted with $\mathrm{H}_{2} \mathrm{O}$. The appropriate 
Table 9. IR, mass and ${ }^{1} \mathrm{H}$ NMR data for new cephalosporins.

\begin{tabular}{|c|c|c|c|}
\hline Compound & $\begin{array}{c}\text { IR } v_{\max }(\mathrm{KBr}) \\
\left(\mathrm{cm}^{-1}\right)\end{array}$ & SI-MS $(m / z)$ & ${ }^{1} \mathrm{H}$ NMR $\left(\mathrm{D}_{2} \mathrm{O}\right) \delta(\mathrm{ppm})$ \\
\hline $\mathbf{3 a}$ & $1760,1640,1610$ & $\begin{array}{c}587(\mathrm{M}+\mathrm{H})^{+} \text {as } \\
\text { mono Na salt }\end{array}$ & $\begin{array}{l}2.12,2.13(3 \mathrm{H}, \mathrm{s}), 3.35,3.42(1 \mathrm{H}, \mathrm{d}), 3.63,3.68 \\
(1 \mathrm{H}, \mathrm{d}), 4.72,4.74(1 \mathrm{H}, \mathrm{d}), 4.89,4.90(1 \mathrm{H}, \mathrm{d}) \\
5.14,5.18(1 \mathrm{H}, \mathrm{d}), 5.60(1 \mathrm{H}, \mathrm{s}), 5.70,5.77(1 \mathrm{H}, \mathrm{d}) \\
6.77,6.82(1 \mathrm{H}, \mathrm{s}), 7.03(1 \mathrm{H}, \mathrm{d}), 7.15(1 \mathrm{H}, \mathrm{dd})\end{array}$ \\
\hline $3 c$ & $1760,1655,1615$ & $\begin{array}{c}609(\mathrm{M}+\mathrm{H})^{+} \text {as } \\
\text { di } \mathrm{Na} \text { salt }\end{array}$ & $\begin{array}{l}2.12,2.13(3 \mathrm{H}, \mathrm{s}), 3.34,3.41(1 \mathrm{H}, \mathrm{d}), 3.64,3.68 \\
(1 \mathrm{H}, \mathrm{d}), 4.72,4.74(1 \mathrm{H}, \mathrm{d}), 4.90,4.91(1 \mathrm{H}, \mathrm{d}) \\
5.14,5.18(1 \mathrm{H}, \mathrm{d}), 5.59,5.60(1 \mathrm{H}, \mathrm{s}), 5.68,5.76 \\
(1 \mathrm{H}, \mathrm{d}), 6.75,6.80(1 \mathrm{H}, \mathrm{s}), 8.13(2 \mathrm{H}, \mathrm{s})\end{array}$ \\
\hline 3d & $1765,1670,1610$ & & $\begin{array}{l}2.14(3 \mathrm{H}, \mathrm{s}), 3.39,3.46(1 \mathrm{H}, \mathrm{d}), 3.66,3.71(1 \mathrm{H}, \mathrm{d}) \\
4.74,4.76(1 \mathrm{H}, \mathrm{d}), 4.90,4.91(1 \mathrm{H}, \mathrm{d}), 5.15,5.19 \\
(1 \mathrm{H}, \mathrm{d}), 5.58,5.59(1 \mathrm{H}, \mathrm{s}), 5.5 \sim 5.8(1 \mathrm{H}), 5.72,5.79 \\
(1 \mathrm{H}, \mathrm{d}), 6.7 \sim 6.85(1 \mathrm{H}), 6.79,6.83(1 \mathrm{H}, \mathrm{s})\end{array}$ \\
\hline $3 e$ & $1765,1660,1610$ & & $\begin{array}{l}2.12,2.13(3 \mathrm{H}, \mathrm{s}), 3.35,3.43(1 \mathrm{H}, \mathrm{d}), 3.65,3.69 \\
(1 \mathrm{H}, \mathrm{d}), 4.72,4.75(1 \mathrm{H}, \mathrm{d}), 4.89,4.91(1 \mathrm{H}, \mathrm{d}), 5.14 \\
5.18(1 \mathrm{H}, \mathrm{d}), 5.60(1 \mathrm{H}, \mathrm{s}), 5.69,5.77(1 \mathrm{H}, \mathrm{d}), 6.69 \\
(1 \mathrm{H}, \mathrm{d}), 6.78,6.83(1 \mathrm{H}, \mathrm{s}), 8.08(1 \mathrm{H}, \mathrm{d}), 8.21(1 \mathrm{H}, \mathrm{br} \mathrm{s})\end{array}$ \\
\hline $4 f$ & $1765,1615,1515$ & $686(\mathrm{M}+\mathrm{H})^{+}$ & $\begin{array}{l}2.26(2 \mathrm{H}, \mathrm{m}), 2.90(2 \mathrm{H}, \mathrm{m}), 3.21(2 \mathrm{H}, \mathrm{m}), 3.37,3.43 \\
(1 \mathrm{H}, \mathrm{d}), 3.62,3.66(1 \mathrm{H}, \mathrm{d}), 4.01(3 \mathrm{H}, \mathrm{s}), 4.10,4.12 \\
(1 \mathrm{H}, \mathrm{d}), 4.35,4.39(1 \mathrm{H}, \mathrm{d}), 5.05,5.07(1 \mathrm{H}, \mathrm{d}), 5.57 \\
(1 \mathrm{H}, \mathrm{s}), 5.58,5.68(1 \mathrm{H}, \mathrm{d}), 6.75,6.78(1 \mathrm{H}, \mathrm{s}), 6.80 \\
7.14(1 \mathrm{H}, \mathrm{d}), 7.52(1 \mathrm{H}, \mathrm{m}), 8.15(1 \mathrm{H}, \mathrm{m})\end{array}$ \\
\hline $6 \mathrm{~g}$ & $\begin{array}{l}1765,1660,1630 \\
1500,1495\end{array}$ & $646(\mathrm{M}+\mathrm{H})^{+}$ & $\begin{array}{l}3.54,3.58(2 \mathrm{H}, \mathrm{ABq}), 4.29,4.32(2 \mathrm{H}, \mathrm{ABq}), 4.22 \\
(3 \mathrm{H}, \mathrm{s}), 5.09,5.13(1 \mathrm{H}, \mathrm{d}), 5.62(1 \mathrm{H}, \mathrm{s}), 5.62,5.73 \\
(1 \mathrm{H}, \mathrm{d}), 6.76,6.81(1 \mathrm{H}, \mathrm{s}) 7.39,7.40(1 \mathrm{H}, \mathrm{s}), 7.63 \\
7.64(1 \mathrm{H}, \mathrm{s}), 7.81(2 \mathrm{H}, \mathrm{d}), 8.40(2 \mathrm{H}, \mathrm{d})\end{array}$ \\
\hline $7 g$ & $\begin{array}{l}1760,1660,1625 \\
1600,1515,1495\end{array}$ & $\begin{array}{c}698(\mathrm{M}+\mathrm{H})^{+} \text {as } \\
\text { mono Na salt }\end{array}$ & $\begin{array}{l}3.37,3.43(1 \mathrm{H}, \mathrm{d}), 3.63,3.68(1 \mathrm{H}, \mathrm{d}), 4.01(2 \mathrm{H}, \mathrm{t}) \\
4.14,4.17(1 \mathrm{H}, \mathrm{d}), 4.37,4.40(1 \mathrm{H}, \mathrm{d}), 4.53(2 \mathrm{H}, \mathrm{m}) \\
5.07,5.11(1 \mathrm{H}, \mathrm{d}), 5.60(1 \mathrm{H}, \mathrm{s}), 5.61,5.70(1 \mathrm{H}, \mathrm{d}) \\
6.73,6.77(1 \mathrm{H}, \mathrm{s}), 7.29,7.30(1 \mathrm{H}, \mathrm{s}), 7.52,7.54 \\
(1 \mathrm{H}, \mathrm{s}), 7.79(2 \mathrm{H}, \mathrm{m}), 8.43(2 \mathrm{H}, \mathrm{m})\end{array}$ \\
\hline 25 & $\begin{array}{l}1760,1660,1600 \\
1515\end{array}$ & $\begin{array}{c}683(\mathrm{M}+\mathrm{H})^{+} \text {as } \\
\text { di Na sait }\end{array}$ & $\begin{array}{l}3.34,3.40(1 \mathrm{H}, \mathrm{d}), 3.67,3.71(1 \mathrm{H}, \mathrm{d}), 3.90,3.92 \\
(1 \mathrm{H}, \mathrm{d}), 4.32,4.37(1 \mathrm{H}, \mathrm{d}), 5.06,5.09(1 \mathrm{H}, \mathrm{d}), 5.59 \\
5.60(1 \mathrm{H}, \mathrm{s}), 5.59,5.68(1 \mathrm{H}, \mathrm{d}), 6.73,6.78(1 \mathrm{H}, \mathrm{s}) \\
7.37(1 \mathrm{H}, \mathrm{s}), 7.61(1 \mathrm{H}, \mathrm{s}), 8.68,8.69(1 \mathrm{H}, \mathrm{s})\end{array}$ \\
\hline 31 & $\begin{array}{l}1760,1660,1600 \\
1515,1500\end{array}$ & $\begin{array}{c}732(\mathrm{M}+\mathrm{H})^{+} \text {as } \\
\text { di Na salt }\end{array}$ & $\begin{array}{l}3.30,3.38(1 \mathrm{H}, \mathrm{d}), 3.63,3.68(1 \mathrm{H}, \mathrm{d}), 4.02,4.06 \\
(1 \mathrm{H}, \mathrm{d}), 4.49,4.53(1 \mathrm{H}, \mathrm{d}), 4.96,5.01(1 \mathrm{H}, \mathrm{d}), 5.56 \\
(1 \mathrm{H}, \mathrm{s}), 5.56,5.66(1 \mathrm{H}, \mathrm{d}), 6.70,6.73(1 \mathrm{H}, \mathrm{s}), 7.27 \\
7.31(1 \mathrm{H}, \mathrm{s}), 7.36(1 \mathrm{H}, \mathrm{m}), 7.46(1 \mathrm{H}, \mathrm{m}), 7.53,7.55 \\
(1 \mathrm{H}, \mathrm{s}), 7.76(1 \mathrm{H}, \mathrm{d}), 7.81(1 \mathrm{H}, \mathrm{d})\end{array}$ \\
\hline 40 & $\begin{array}{l}1765,1660,1625 \\
1600,1495\end{array}$ & $672(\mathrm{M}+\mathrm{H})^{+}$ & $\begin{array}{l}1.30(4 \mathrm{H}, \mathrm{m}), 3.36,3.42(1 \mathrm{H}, \mathrm{d}), 4.38,4.42(1 \mathrm{H}, \mathrm{d}) \\
5.05,5.09(1 \mathrm{H}, \mathrm{d}), 5.57(1 \mathrm{H}, \mathrm{s}), 5.58,5.68(1 \mathrm{H}, \mathrm{d}) \\
6.73,6.77(1 \mathrm{H}, \mathrm{s}), 7.37,7.38(1 \mathrm{H}, \mathrm{s}), 7.59,7.60 \\
(1 \mathrm{H}, \mathrm{s}), 7.76(2 \mathrm{H}, \mathrm{m}), 8.52(2 \mathrm{H}, \mathrm{d})\end{array}$ \\
\hline
\end{tabular}

fractions were collected, concentrated and lyophilized to give $\mathbf{3 f}$ as the sodium salt $(185 \mathrm{mg}, 54 \%)$ : IR $(\mathrm{KBr}) \mathrm{cm}^{-1} 1760,1660,1605,1515 ;{ }^{1} \mathrm{H}$ NMR $\left(\mathrm{D}_{2} \mathrm{O}\right) \delta 2.08$ and 2.09 (total $3 \mathrm{H}$, each s), 3.31 and 3.37 $(1 \mathrm{H}, \mathrm{d}), 3.61$ and $3.64(1 \mathrm{H}, \mathrm{d}), 4.76 \sim 4.90(2 \mathrm{H}), 5.10$ and $5.14(1 \mathrm{H}, \mathrm{d}), 5.54$ and $5.57(1 \mathrm{H}, \mathrm{s}), 5.63$ and $5.74(1 \mathrm{H}, \mathrm{d}), 6.75 \sim 6.85(2 \mathrm{H}), 7.23(1 \mathrm{H}, \mathrm{d}) ;$ SI-MS $m / z 603(\mathrm{M}+\mathrm{H})^{+}$.

$(6 R, 7 R)-7-[(R S)$-2-(2-Aminothiazol-4-yl)-2-(1,5-dihydroxy-4-pyridone-2-carboxamido)acetamido]3-(acetoxymethyl)ceph-3-em-4-carboxylic Acid (3g)

(a): To a solution of $7.1 \mathrm{~g}$ of 15 and $4.4 \mathrm{ml}$ of $\mathrm{Et}_{3} \mathrm{~N}$ in $100 \mathrm{ml}$ of THF was added $5.33 \mathrm{~g}$ of $\mathrm{PCl}_{5}$ at $-10 \sim-15^{\circ} \mathrm{C}$, and the reaction mixture was stirred for 1 hour. This acid chloride solution was added to a solution of $20 \mathrm{mmol}$ of 2 in a mixture of THF $(100 \mathrm{ml})$ and $\mathrm{H}_{2} \mathrm{O}(200 \mathrm{ml})$ at $\mathrm{pH} 8.0 \sim 8.5$ adjusted with 
$\mathrm{Et}_{3} \mathrm{~N}$ under ice-cooling. After stirring at $0^{\circ} \mathrm{C}$ for 1 hour maintaining the $\mathrm{pH}$ at $8.0 \sim 8.5$ with $\mathrm{Et}_{3} \mathrm{~N}$, the reaction mixture was concentrated and acidified to $\mathrm{pH} 2$ with $1 \mathrm{~N} \mathrm{HCl}$. The precipitate was collected, washed with $\mathrm{H}_{2} \mathrm{O}$ and dried to give crude $(6 R, 7 R)-7-[(R S)-2-(2$-aminothiazol-4-yl)-2-[1-hydroxy-5-( $p$ methoxybenzyloxy)-4-pyridone-2-carboxamido]acetamido]-3-(acetoxymethyl)ceph-3-em-4-carboxylic acid $(9.2 \mathrm{~g})$.

(b): To a suspension of $9.2 \mathrm{~g}$ of the product obtained in (a) in anisole $(22 \mathrm{ml})$ was added dropwise $97 \mathrm{ml}$ of TFA at $0^{\circ} \mathrm{C}$. The reaction mixture was stirred at room temperature for 30 minutes, and poured into $700 \mathrm{ml}$ of isopropyl ether. The precipitate was collected by filtration, dried, then dissolved in satd aq $\mathrm{NaHCO}_{3}$ and purified by Diaion HP-20 column chromatography with elution by $\mathrm{H}_{2} \mathrm{O}$ and $5 \%$ aq $\mathrm{Me}_{2} \mathrm{CO}$ to afford $3 \mathrm{~g}$ as the sodium salt $(3.34 \mathrm{~g}, 27.7 \%$ from 2$)$ : IR $(\mathrm{KBr}) \mathrm{cm}^{-1} 1760,1670,1610,1510 ;{ }^{1} \mathrm{H}$ NMR $\left(\mathrm{D}_{2} \mathrm{O}\right) \delta 2.11$ and $2.12(3 \mathrm{H}, \mathrm{s}), 3.48$ and $3.55(1 \mathrm{H}, \mathrm{ABq}), 4.79$ and $4.82(1 \mathrm{H}, \mathrm{ABq}), 5.11$ and $5.15(1 \mathrm{H}, \mathrm{d})$, 5.60 and $5.62(1 \mathrm{H}, \mathrm{s}), 5.65$ and $5.75(1 \mathrm{H}, \mathrm{d}), 6.75$ and $6.80(1 \mathrm{H}, \mathrm{s}), 7.48(1 \mathrm{H}, \mathrm{s}), 7.60(1 \mathrm{H}, \mathrm{s})$; SI-MS $m / z$ $603(\mathrm{M}+\mathrm{H})^{+}$.

$(6 R, 7 R)-7-[(R S)$-2-(2-Aminothiazol-4-yl)-2-(1,5-dihydroxy-4-pyridone-2-carboxamido)acetamido]3-[(1-methylcyclopentano[b]-pyridinium-4-yl)thiomethyl]ceph-3-em-4-carboxylate $\mathbf{( 4 g )}$

To a solution of $600 \mathrm{mg}$ of $3 \mathrm{~g}$ in $10 \mathrm{ml}$ of $50 \%$ aq $\mathrm{CH}_{3} \mathrm{CN}$ was added $\mathrm{NaI}(1.5 \mathrm{~g})$ and 1 -methylcyclopentano $[b]$ pyridine-4-thione $(250 \mathrm{mg})$. The reaction mixture was stirred at $70^{\circ} \mathrm{C}$ for 3 hours, cooled to room temperature and poured into $50 \mathrm{ml}$ of $\mathrm{Me}_{2} \mathrm{CO}$. The precipitate was collected by filtration, and purified by column chromatography on Diaion HP-20 with elution by $5 \sim 10 \%$ aq $\mathrm{Me}_{2} \mathrm{CO}$ and on Sephadex LH-20 with elution by $50 \%$ aq $\mathrm{MeOH}$. The appropriate fractions were collected, evaporated and lyophilized to provide $4 \mathrm{~g}(150 \mathrm{mg}, 21.9 \%)$ : IR $(\mathrm{KBr}) \mathrm{cm}^{-1} 1765,1660,1615,1515,1500 ;{ }^{1} \mathrm{H} \mathrm{NMR}$ $\left(\mathrm{D}_{2} \mathrm{O}\right) \delta 2.28(2 \mathrm{H}, \mathrm{m}), 3.88(2 \mathrm{H}, \mathrm{m}), 3.21(2 \mathrm{H}, \mathrm{m}), 3.55$ and $3.60(1 \mathrm{H}, \mathrm{ABq}), 4.04(3 \mathrm{H}, \mathrm{s}), 4.26$ and 4.28 $(1 \mathrm{H}, \mathrm{ABq}), 5.09$ and $5.13(1 \mathrm{H}, \mathrm{d}), 5.62$ and $5.72(1 \mathrm{H}, \mathrm{d}), 5.63(1 \mathrm{H}, \mathrm{s}), 6.75$ and $6.79(1 \mathrm{H}, \mathrm{s}), 7.26$ and 7.31 $(1 \mathrm{H}, \mathrm{s}), 7.53(1 \mathrm{H}, \mathrm{d}), 7.54$ and $7.57(1 \mathrm{H}, \mathrm{s}), 8.15(1 \mathrm{H}, \mathrm{d})$; SI-MS $m / z 686(\mathrm{M}+\mathrm{H})^{+}$.

By a similar procedure as described for the preparation of $\mathbf{4 g}$, the desired compounds $4 \sim 7$ and $\mathbf{1 8} \sim \mathbf{4 4}$ were obtained from 3 by substitution of the acetoxy group at C-3 methylene with various kinds of nucleophiles. The IR, mass and ${ }^{1} \mathrm{H}$ NMR data of typical compounds are summarized in Table 9.

Acknowledgment

The authors wish to thank Dr. R. OKamoto for kind advice on the biological study and Ms. S. Miki for the mass spectral data.

\section{References}

1) Tsuruoka, T.; T. Yoshida, K. Katano, S. Nakabayashi, K. Iwamatsu, H. Ogino, T. Okonogi, Y. Murai, I. KomiYa, M. Nishio, Y. Kazuno \& S. InOUYE: New aminothiazole cephalosporins with 3-pyridiniumthiomethyl substituents. Abstracts of the 14th Int. Congr. Chemother., No. P-49-1, p. 420, Kyoto, June 23 28, 1985

2) Ohi, N.; B. Aoki, K. Moro, T. Kuroki, N. Sugimura, T. Noto, T. Nehashi, M. Matsumoto, H. OKazaki \& I. Matsunaga: Semisynthetic $\beta$-lactam antibiotics. II. Effect on antibacterial activity of ureido $N$-substituents in the 6-[( $R)$-2-[3-(3,4-dihydroxybenzoyl)-1-ureido]-2-phenylacetamido]penicillanic acids. J. Antibiotics 39: 242 250, 1986

3) Mochizuki, H.; Y. Oikawa, H. Yamada, S. Kusakabe, T. Shilhara, K. Murakami, K. Kato, J. Ishiguro \& H. Kosuzume: Antibacterial and pharmacokinetic properties of M14659, a new injectable semisynthetic cephalosporin. J. Antibiotics 41: 377 391, 1988

4) Ohi, N.; B. Aoki, T. Kuroki, M. Matsumoto, K. Kojima \& T. Nehashi: Semisynthetic $\beta$-lactam antibiotics. III. Effect on antibacterial activity and COMT-susceptibility of chlorine-introduction into the catechol nucleus of 6-[(R)-2-[3-(3,4-dihydroxybenzoyl)-3-(3-hydroxypropyl)-1-ureido]-2-phenylacetamido]penicillanic acid. J. Antibiotics 40: $22 \sim 28,1987$

5) Mochida, K.; Y. Ono, M. Yamasaki, C. Shiraki, T. Hirata, K. Sato \& R. Okachi: Aminothiazolylglycyl derivatives of carbacephem antibiotics. II. Synthesis and antibacterial activity of novel aminothiazolyl cephem compounds with hydroxypyridone moiety. J. Antibiotics 40: 182 189, 1987

6) Ogino, H.; K. Iwamatsu, K. Katano, S. Nakabayashi, T. Yoshida, S. Shibahara, T. Tsuruoka, S. Inouye \& S. KONDO: New aminothiazolylglycylcephalosporins with a 1,5-dihydroxy-4-pyridone-2-carbonyl group. II. 
Synthesis and antibacterial activity of MT0703 and its diastereomers. J. Antibiotics 43: 189 198, 1990

7) Ochiai, M.; A. Morimoto, T. Okada, Y. Matsushita, H. Yamamoto, O. Aki \& M. Kidd: Synthesis and

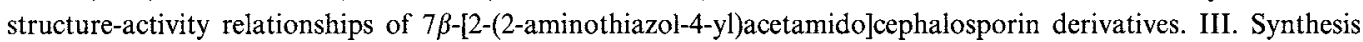
and antibacterial activity of 7 $\beta$-[2-amino-2-(2-aminothiazol-4-yl)acetamido]cephalosporins. J. Antibiotics 33: $1022 \sim 1030,1980$

8) Tsuruoka, T.; T. Niwa, S. Inouye, T. Ito \& T. NIIDA (Meiji Seika Kaisha): Preparation of glucaro-1,5-lactam, 5-amino-5-deoxy-D-glucosaccharic acid-1,5-lactam. Jpn. Pat. 4528375 ('80), Sept. 16, 1970

9) Nakagawa, K.; R. Konaka \& T. Nakata: Oxidation with nickel peroxide. I. Oxidation of alcohols. J. Org. Chem. 27: $1597 \sim 1601,1962$ 